American Journal of Biochemistry and Biotechnology 5 (1): 21-29, 2009

ISSN 1553-3468

(C) 2009 Science Publications

\title{
Classification of Pressure Range Based on the Characterization of Escherichia coli Cell Disruption in High Pressure Homogenizer
}

\author{
${ }^{1}$ Ramakrishnan Nagasundara Ramanan, ${ }^{1,2}$ Beng Ti Tey, ${ }^{3}$ Tau Chuan Ling and ${ }^{1,4}$ Arbakariya B. Ariff \\ ${ }^{1}$ Institute of Bioscience, University Putra Malaysia, 43400 Serdang, Selangor, Malaysia \\ ${ }^{2}$ Department of Chemical and Environmental Engineering, Faculty of Engineering, \\ University Putra Malaysia, 43400 UPM Serdang, Selangor, Malaysia \\ ${ }^{3}$ Department of Process and Food Engineering, Faculty of Engineering, University Putra Malaysia, \\ 43400 UPM Serdang, Selangor, Malaysia \\ ${ }^{4}$ Department of Bioprocess Technology, Faculty of Biotechnology and Biomolecular Sciences, \\ University Putra Malaysia, 43400 UPM Serdang, Selangor, Malaysia
}

\begin{abstract}
Problem statement: High pressure Homogenizer was used for cell disruption in many studies. But no work was carried out to study the characteristics of cell disruption in a wide range of pressure. Approach: The characteristics of Escherichia coli cell disruption was studied in Avestin small scale homogenizer by varying the operating pressure (50-1500 bar), cell concentration in the feed (1.39-12.51 g dry cell weight $\mathrm{L}^{-1}$ ) and number of passes (1-5 passes). Results: It was found that cell concentration between $1.39 \mathrm{~g}$ dry cell weight $\mathrm{L}^{-1}$ and $12.51 \mathrm{~g}$ dry cell weight $\mathrm{L}^{-1}$ has no effect on cell disruption while the pressure applied and number of passes gave different effects on cell disruption characteristics. In between 100 and 250 bar, the protein release was mainly due to point break. In this case, the variation in cell size was not significant with increasing number of passes and maximum protein release was not achieved even after many numbers of pass. However, selectivity of specific protein (interferon- $\alpha 2 b$ ) was high as it is located predominantly in periplasmic region. In between 1000 and $1500 \mathrm{bar}$, the maximum protein release, maximum interferon- $\alpha 2 \mathrm{~b}$ release and drastic reduction of cell size was observed after the first pass. In subsequent passes, micronization of cell debris was observed but without much variation in protein release. There was no reduction in antigenicity of interferon- $\alpha 2 \mathrm{~b}$ even at 1500 bar. At 500 bar, the protein release and reduction of cell size were significantly increased with increasing number of passes. Conclusion: The pressure range for $E$. coli cell disruption was classified as low pressure range (100-250 bar), transition pressure (500 bar) and high pressure range (1000-1500 bar). The working pressure for the homogenizer could be selected by considering the operating cost and further downstream processing.
\end{abstract}

Key words: cell disruption, homogenizer, Escherichia coli, protein release, interferon- $\alpha 2 b$

\section{INTRODUCTION}

High pressure homogenization was initially used in the dairy and emulsion industry ${ }^{[1,2]}$ but eventually adopted for application in cell disruption. Cell disruption is important downstream processing step for the recovery of intracellular products. In homogenizer, cell suspensions are pressurized by positive displacement pump and passed through valve and impactor arrangement to disintegrate the cell. The different valve characteristics and impactor arrangement yield different performances of cell disruption for different microorganisms The details design of valve and impactor arrangement and its effect on the disruption of various microorganisms have been discussed and reviewed elsewhere ${ }^{[3-5]}$.

APV homogenizers with different valve types are widely used for microbial cell disruption. A typical small-scale machine (APV-Gaulin 15M homogenizer) can be operated at a pressure as high as $750 \mathrm{bar}^{[5]}$. On the other hand, small-scale machine from Avestin (Emulsiflex-C50) can be operated at a wide range of pressure up to 2000 bar. Avestin homogenizer is widely used in emulsion industries and its related work.

Corresponding Author: Arbakariya B. Ariff, Department of Bioprocess Technology, Faculty of Biotechnology and Biomolecular Sciences, University Putra Malaysia, 43400 UPM Serdang, Selangor, Malaysia Tel: +603-8946 7516 Fax: + 603-8946 7510 
Although, this equipment has been reported for the use in cell disruption ${ }^{[6-8]}$, no optimization work or characterization of cell disruption using this machine are available in the literature.

Therefore, the objective of this study was to assess the characteristics of Escherichia coli cell disintegration in a wide range of pressure with Avestin homogenizer. E. coli producing interferon- $\alpha 2 \mathrm{~b}$ (IFN- $\alpha 2 \mathrm{~b}$ ) was used as a model microorganism in this study. The effect of applied pressure, cell concentration and number of passes on the performance of Avestin homogenizer in cell disruption were assessed for the reduction in cell viability, Particle Size Distribution (PSD), power and time requirement, total protein release, and IFN- $\alpha 2 b$ release.

\section{MATERIALS AND METHODS}

Feedstock preparation: $E$. coli strain Rosetta-gami 2(DE3) producing IFN- $\alpha 2 b$ was used in this study. This E. coli strain harbors pET-26b-IFN plasmid which contains T7lac promoter and pelB signal sequence to aid the transfer of IFN- $\alpha 2 b$ to periplasmic area. pET-26b-IFN was prepared by subcloning the coding sequence of IFN- $\alpha 2 b$ from the source plasmid pALCA1SIFN (ATCC 53369) to the target plasmid pET-26b (Cat. No. 69862-3, Novagen). The culture medium consists of $60 \mathrm{~g} \mathrm{~L}^{-1}$ of overnight express instant terrific broth (Auto induction medium, Merck). $10 \mathrm{~mL}$ of sterile glycerol was added to the sterile medium along with antibiotics $\left(34 \mathrm{mg} \mathrm{L}^{-1}\right.$ of chloramphenicol and $30 \mathrm{mg} \mathrm{L}^{-1}$ of kanamycin). The medium was inoculated with $1 \%$ of stock culture and was incubated in a rotary shaker (Certomat ${ }^{\circledR}$ BS-1 B. Braun, Germany) operating at $225 \mathrm{rpm}$ and $37^{\circ} \mathrm{C}$. After $24 \mathrm{~h}$ cultivation, the cells were harvested by centrifugation (rotor model 1619, Universal 32R centrifuge, Hettich AG, Switzerland) at $3750 \times \mathrm{g}$ for $15 \mathrm{~min}$ at $25^{\circ} \mathrm{C}$ and the collected cells were re-suspended in ultra pure water to get the required concentration.

Cell disruption by high pressure homogenizer: Cell suspension with appropriate biomass concentration (Dry cell weight $(\mathrm{DCW})=1.39,5.56$ or $12.51 \mathrm{~g} \mathrm{~L}^{-1}$ ) was passed through high pressure homogenizer (Emulsiflex-C50, Avestin) and then through shell and tube heat exchanger. The cooling water (maintained between 5 and $10^{\circ} \mathrm{C}$ ) was circulated into the tube side of the heat exchanger. The pressure of the homogenizer was adjusted between 50 and 1500 bar according to the need of each experiment. Samples were taken at each pass for the analysis of cell viability, particle size distribution, viscosity, total protein quantification, electrophoresis and IFN- $\alpha 2 b$ quantification. In between the experimental run, homogenizer was cleaned for 5 min with $50 \%$ ethanol, followed by ultra pure water for three times to completely remove the residual ethanol.

Cell disruption by glass bead shaking: Cell disruption by glass bead shaking was done according to the method described previously ${ }^{[9]}$. Briefly $4 \mathrm{~mL}$ of cell suspension $\left(\mathrm{DCW}=5.56 \mathrm{~g} \mathrm{~L}^{-1}\right)$ was mixed with $6 \mathrm{~g}$ of glass beads $(0.5 \mathrm{~mm}$ dia $)$ in a $50 \mathrm{~mL}$ Falcon tube and rotated at $300 \mathrm{rpm}$ in a rotary shaker for $30 \mathrm{~min}$.

Cell disruption by osmotic shock: Cell disruption by osmotic shock was done according to the method as described by Chen et al. ${ }^{[10]}$ with slight modification. Briefly, cell pellets were re-suspended in ice cold water $\left(\mathrm{DCW}=5.56 \mathrm{~g} \mathrm{~L}^{-1}\right)$ and incubated for $10 \mathrm{~min}$ with shaking. After centrifugation at $8,000 \times \mathrm{g}$ (rotor model 1189, Universal 22R centrifuge, Hettich AG, Switzerland) for $10 \mathrm{~min}$, the resulting pellets were re-suspended in hypertonic solution (20\% sucrose in $33 \mathrm{mM}$ of Tris-HCl, pH 8.0 and $5 \mathrm{mM}$ of EDTA) and kept with shaking for $10 \mathrm{~min}$. The cell suspension was again centrifuged $(10,000 \times \mathrm{g}, 10 \mathrm{~min})$ to harvest the shrunk cells and then re-suspended in ice-cooled water. The cell suspension was incubated with $10 \mathrm{~min}$ of shaking. The periplasmic protein was recovered after separating the cells from solution by centrifuging at $10,000 \times \mathrm{g}$ for $10 \mathrm{~min}$.

\section{Analytical procedures:}

Cell concentration: The cell concentration was analyzed by Optical Density (OD) using UV/VIS spectrometer (Perkin Elmer, Lambda 25) at $600 \mathrm{~nm}$ wave lengths and then correlated with DCW. The $\mathrm{OD}_{600}$ was used to indicate the cell concentration of feedstock, their $\mathrm{OD}_{600}$ value was being fixed at 5, 20 or 45 according to the experimental conditions. The DCW correlation (1 $\mathrm{OD}_{600}=0.278 \mathrm{~g} \mathrm{DCW} \mathrm{L}^{-1}$ ) for $\mathrm{OD}_{600} 5,20$ and 40 were found to be $1.39,5.56$ and $12.51 \mathrm{~g} \mathrm{~L}^{-1}$ respectively.

Cell viability: Test samples were serially diluted in sterile condition and were spread in triplicates in the LB agar plates containing $34 \mathrm{mg} \mathrm{L}^{-1}$ of chloramphenicol and $30 \mathrm{mg} \mathrm{L}^{-1}$ of kanamycin. After the overnight incubation at $37^{\circ} \mathrm{C}$, the number of colonies was counted and expressed as Colony Forming Unit (CFU). The difference from initial value was taken and reported as percentage of reduction in cell viability.

Particle size distribution analysis: Particle Size Distribution (PSD) analysis was done using dynamic 
light scattering method in Nanophox PCCS (Sympatec $\mathrm{GmbH})$. The temperature of the instrument was maintained at $25^{\circ} \mathrm{C}$ throughout the experiment. The samples were diluted in water to get the count rate of $250( \pm 75)$. Each assay was conducted in triplicates.

Viscosity measurement: Viscosity was determined using DV-II viscometer (Brookfield Eng. Lab.) where the spindle (SC4-18) was rotated at a standard speed of $100 \mathrm{rpm}$. Each assay was conducted in triplicates

Total protein quantification: Total Protein content was analyzed by Bradford method ${ }^{[11]}$ using bio-rad protein assay kit manual. Bovine Serum Albumin (BSA) was used as a standard in the linear dilution range of 0.1-0.5 $\mathrm{mg} \mathrm{mL}^{-1}$. Samples and standards were placed in the 96 well plate flat bottoms and the absorbance was measured at $595 \mathrm{~nm}$ using micro plate reader (Tecan sunrise Absorbance reader). Both samples and standards were analyzed in triplicates. Standard deviation was found to be less than 0.35 and percentage of coefficient variance was found to be less than $6 \%$.

Sodium dodecyl sulfate-polyacrylamide gel electrophoresis (SDS-PAGE) analysis: The presence of IFN- $\alpha 2 b$ was detected using SDS-PAGE (15\% resolving gel and 5\% stacking gel) and Coomassie Brilliant Blue R-250 staining. Electrophoresis was conducted at $130 \mathrm{~V}$ using a Mini-Protean 3 apparatus (Bio-Rad) in Tris-glycine buffer.

Antigenicity and quantification of IFN- $22 b$ : Antigenicity of disrupted IFN- $\alpha 2 b$ was ensured by using biosensor in Biacore3000. CM-5 Chip (GE Healthcare, Sweden) was immobilized with anti- $\alpha$ - IFN mouse monoclonal antibody (MMHA-2, catalog No. 407290, Merck, USA). After stabilizing the chip with few pre-runs, $5 \mu \mathrm{L}$ of standards and samples were run through chip and the output was measured as response unit. The standards were calibrated using ELISA Kit (catalog No. RPN2759, GE Healthcare, UK). The quantity of IFN- $\alpha 2 b$ in the samples was estimated from the linear standard curve.

Calculation of selective product release and compressor power requirement: The selective product release was calculated as follows:

Selective product release $\left(\mathrm{ng} \mathrm{mg}^{-1}\right)$

Amount of IFN $-\alpha 2 b\left(\mathrm{ng} \mathrm{mL}^{-1}\right)$

Amount of total protein release $\left(\mathrm{mg} \mathrm{mL}^{-1}\right)$
The calculation of compressor power requirement was taken from the manual supplied by the manufacturer (Avestin). Air required in Standard Cubic Feet (SCF) for different operating pressures was obtained from the manufacturer's chart. The equation was modified to process $100 \mathrm{~L}$ of sample and it is given as below:

Power required $(\mathrm{khp})=1500 \times$ Air required $(\mathrm{SCF})$ to

$$
\text { process } \mathrm{mL}^{-1} \text { of sample }
$$

\section{RESULTS}

Effect of pressure and number of passes: Feedstock with cell concentration of $5.56 \mathrm{~g} \mathrm{DCW} \mathrm{L}^{-1}$ was passed up to 5 passes in six different pressures $(50,100,250$, 500,1000 and 1500 bar). The samples were taken from every passage to analyze the amount of total protein release, the amount of IFN- $\alpha 2 b$ release and PSD. At 50 bar, there was no significant release of protein and reduction in cell viability (result not shown here). This is not surprised since the value of this pressure is below the threshold pressure for disruption to occur. Indeed, Siddiqi et al. ${ }^{[12]}$ have reported that only little breakage was observed for baker's yeast in APV homogenizer operated at pressure below 115 bar.

The maximum protein release (Table 1) of homogenization operated at 100 and 250 bar was low compare to the higher pressures ( $>500 \mathrm{bar}$ ) even after 5 passes. The PSD for 100 bar shows negligible difference with increasing number of passes and for 250 bar, only very little variation could be seen (Fig. 1a and 2a). At 500 bar, both protein release and PSD (Fig. $1 \mathrm{~b}$ and $2 \mathrm{~b}$ ) was varied significantly with the increase in number of passes. At 1000 and 1500 bar, sharp increase of protein release and shift of PSD (Fig. $1 \mathrm{~b}$ and $2 \mathrm{~b}$ ) was observed after 1 pass. With increase in number of passes there was no much difference either in protein release or PSD.

Effect of cell concentration: Culture with three different cell concentrations $\left(1.39,5.56\right.$ and $\left.12.51 \mathrm{~g} \mathrm{~L}^{-1}\right)$ was passed up to 5 passes in homogenizer to investigate the effect of concentrations on low, transition and high pressure ranges. The extent of cell disruption was found by the percent of protein release, percent of reduction of cell viability and finally by PSD analysis. At high and transition pressure range, the difference in cell concentrations did not have any effect in either protein release or in reduction of cell viability (Fig. $3 a$ and $3 b$ ). This is similar to the results published previously for different microorganism including E. coli ${ }^{[13-15]}$. 
Am. J. Biochem. \& Biotech., 5 (1): 21-29, 2009

Table 1: Characteristics of different cell disruption methods

\begin{tabular}{|c|c|c|c|c|c|c|c|}
\hline Sample & $\begin{array}{l}\text { Protein } \\
\left(\mathrm{mg} \mathrm{mL}^{-1}\right)\end{array}$ & $\begin{array}{l}\text { IFN- } \alpha 2 b \\
\left(\mathrm{ng} \mathrm{mL}^{-1}\right)\end{array}$ & $\begin{array}{l}\text { Selective product } \\
\text { release }\left(\mathrm{ng} \mathrm{mg}^{-1}\right)\end{array}$ & $\mathrm{Sv}\left(\mathrm{m} 2 \mathrm{~cm}^{-} 3\right)$ & $\operatorname{VMD}(\mathrm{nm})$ & $\begin{array}{l}\text { Power } \\
\text { requirement (khp) }\end{array}$ & $\begin{array}{l}\text { Time } \\
\text { requirement }(\mathrm{h})\end{array}$ \\
\hline $100-5.56-1$ & 0.103 & 9.647 & 93.337 & 10.29 & 597.07 & 57.00 & 2.02 \\
\hline $100-5.56-2$ & 0.111 & 12.135 & 109.455 & 9.77 & 627.88 & 114.00 & 4.04 \\
\hline $100-5.56-3$ & 0.128 & 10.322 & 80.492 & 10.40 & 588.64 & 171.00 & 6.06 \\
\hline $100-5.56-4$ & 0.120 & 10.008 & 83.220 & 10.33 & 594.73 & 228.00 & 8.08 \\
\hline $100-5.56-5$ & 0.132 & 13.005 & 98.882 & 10.05 & 626.68 & 285.00 & 10.10 \\
\hline $250-5.56-1$ & 0.201 & 21.794 & 108.434 & 10.50 & 614.32 & 57.00 & 2.06 \\
\hline $250-5.56-2$ & 0.469 & 41.151 & 87.788 & 11.24 & 604.97 & 114.00 & 4.12 \\
\hline $250-5.56-3$ & 0.502 & 46.895 & 93.489 & 11.89 & 567.94 & 171.00 & 6.19 \\
\hline $250-5.56-4$ & 0.468 & 43.560 & 93.082 & 12.46 & 536.55 & 228.00 & 8.25 \\
\hline $250-5.56-5$ & 0.491 & 52.543 & 106.915 & 12.93 & 508.94 & 285.00 & 10.31 \\
\hline $500-5.56-1$ & 1.092 & 59.921 & 54.893 & 23.90 & 490.47 & 64.05 & 2.19 \\
\hline $500-5.56-2$ & 1.563 & 92.797 & 59.371 & 40.69 & 308.52 & 128.10 & 4.38 \\
\hline $500-5.56-3$ & 1.687 & 101.564 & 60.204 & 46.11 & 253.02 & 192.15 & 6.58 \\
\hline $500-5.56-4$ & 1.774 & 103.349 & 58.263 & 54.57 & 212.46 & 256.20 & 8.77 \\
\hline $500-5.56-5$ & 1.864 & 106.378 & 57.055 & 59.39 & 158.36 & 320.25 & 10.96 \\
\hline $1000-5.56-1$ & 2.086 & 114.775 & 55.010 & 49.56 & 238.96 & 85.80 & 2.88 \\
\hline $1000-5.56-2$ & 2.451 & 102.119 & 41.662 & 50.92 & 175.13 & 171.60 & 5.76 \\
\hline $1000-5.56-3$ & 2.354 & 136.387 & 57.939 & 54.83 & 148.98 & 257.40 & 8.63 \\
\hline $1000-5.56-4$ & 2.012 & 87.619 & 43.548 & 56.15 & 138.88 & 343.20 & 11.51 \\
\hline $1000-5.56-5$ & 1.508 & 65.803 & 43.625 & 48.36 & 137.44 & 429.00 & 14.39 \\
\hline $1500-5.56-1$ & 1.893 & 92.550 & 48.892 & 55.29 & 173.76 & 107.55 & 4.19 \\
\hline $1500-5.56-2$ & 1.647 & 101.172 & 61.416 & 51.48 & 176.02 & 215.10 & 8.38 \\
\hline $1500-5.56-3$ & 2.136 & 116.573 & 54.574 & 53.63 & 136.97 & 322.65 & 12.57 \\
\hline $1500-5.56-4$ & 1.739 & 100.938 & 58.040 & 48.73 & 132.57 & 430.20 & 16.76 \\
\hline $1500-5.56-5$ & 1.878 & 82.079 & 43.705 & 53.47 & 123.24 & 537.75 & 20.95 \\
\hline Glass bead shaking & 1.911 & 112.472 & 58.808 & ND & ND & ND & ND \\
\hline Osmotic shock & 0.139 & 73.249 & 526.591 & 10.00 & 632.28 & ND & ND \\
\hline Before disruption & 0.000 & 0.000 & 0.000 & 9.08 & 680.76 & ND & ND \\
\hline
\end{tabular}

Samples passed into high pressure homogenizer were denoted as pressure in bar followed by cell concentration in $\mathrm{g} \mathrm{L}^{-1}$ and number of passes. Selective product release was calculated using equation 1. Specific surface area $\left(S_{V}\right)$ and volumetric mean diameter (VMD) were taken from particle size analysis. Power requirement (equation 2) and time requirement were calculated according to the manufacturer's manual

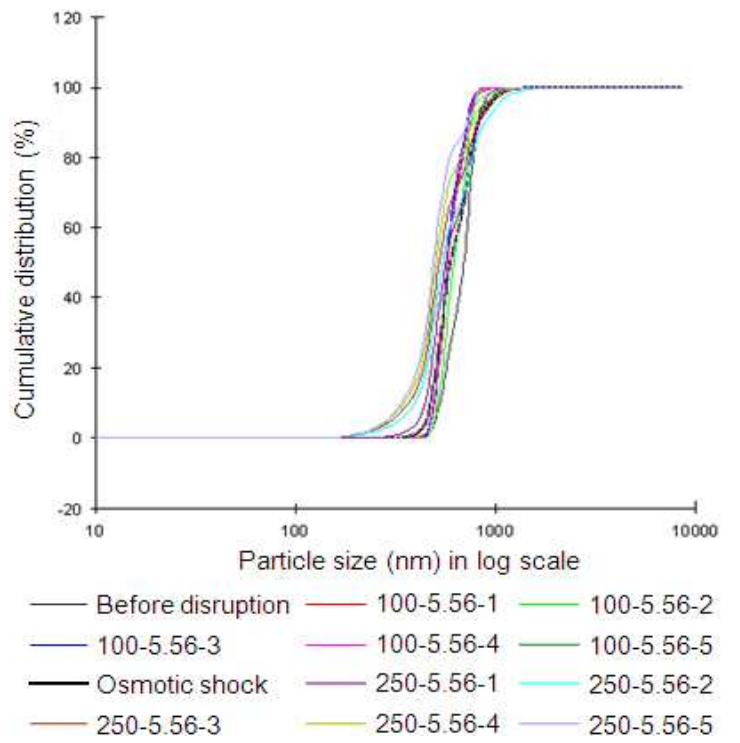

Fig. 1a: Cumulative distribution of before distribution, osmotic shock and low pressure range after each number of passes for 5.56 DCW g L $\mathrm{D}^{-1}$ of cell concentration. The legend indicates the pressure in bar followed by cell concentration in $\mathrm{g} \mathrm{L}^{-1}$ and number of passes. The data are the average of replicates

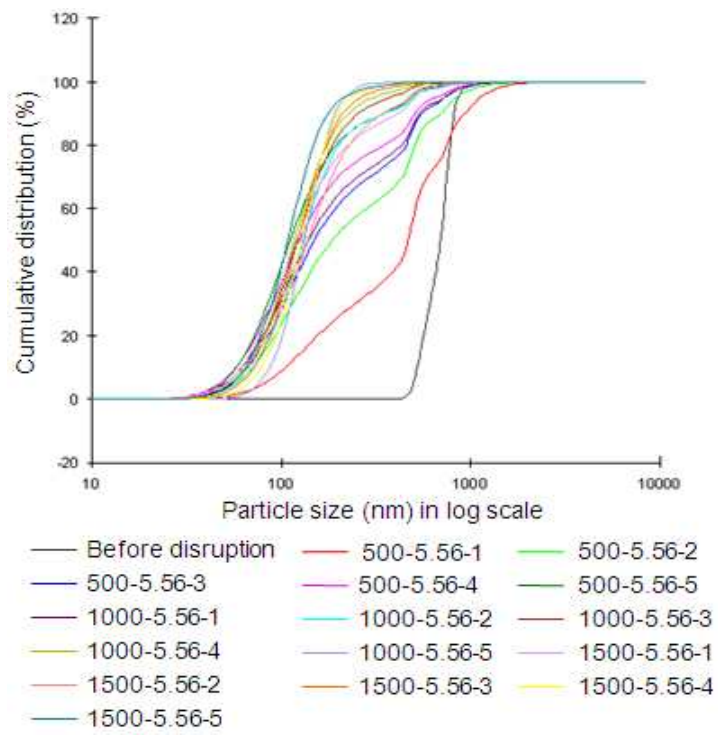

Fig. 1b: Cumulative distribution of before distribution transition and high pressure ranges after each number of passes for 5.56 DCW g L ${ }^{-1}$ of cell concentration. The legend indicates the pressure in bar followed by cell concentration in $\mathrm{g} \mathrm{L}^{-1}$ and number of passes. The data are the average of replicates 
Am. J. Biochem. \& Biotech., 5 (1): 21-29, 2009

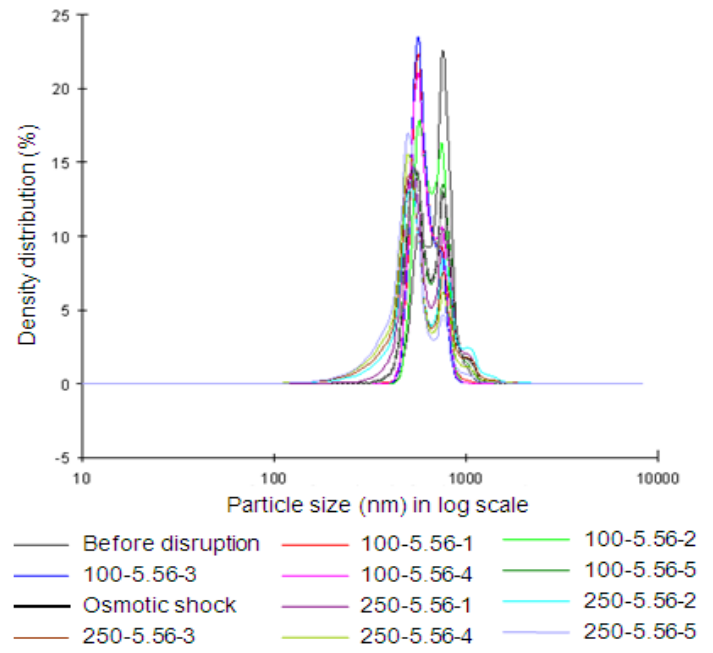

Fig. 2a: Density distribution of before distribution, osmotic shock and low pressure range after each number of passes for $5.56 \mathrm{DCW} \mathrm{g} \mathrm{L}^{-1}$ of cell concentration. The legend indicates the pressure in bar followed by cell concentration in $\mathrm{g} \mathrm{L}^{-1}$ and number of passes. The data are the average of replicates

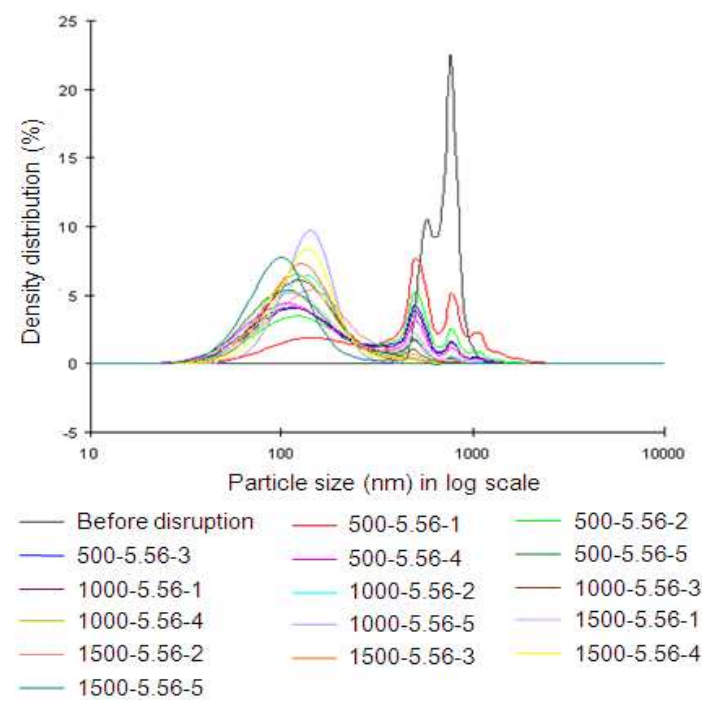

Fig. 2b: Density distribution of before distribution, transition and high pressure ranges after each number of passes for 5.56 DCW g L $\mathrm{D}^{-1}$ of cell concentration. The legend indicates the pressure in bar followed by cell concentration in $\mathrm{g} \mathrm{L}^{-1}$ and number of passes. The data are the average of replicates

At low pressure range, the percent reduction of cell viability was found to be similar in all cell concentrations where as the difference was observed in protein release between $1.39 \mathrm{~g} \mathrm{~L}^{-1}$ and other concentrations.

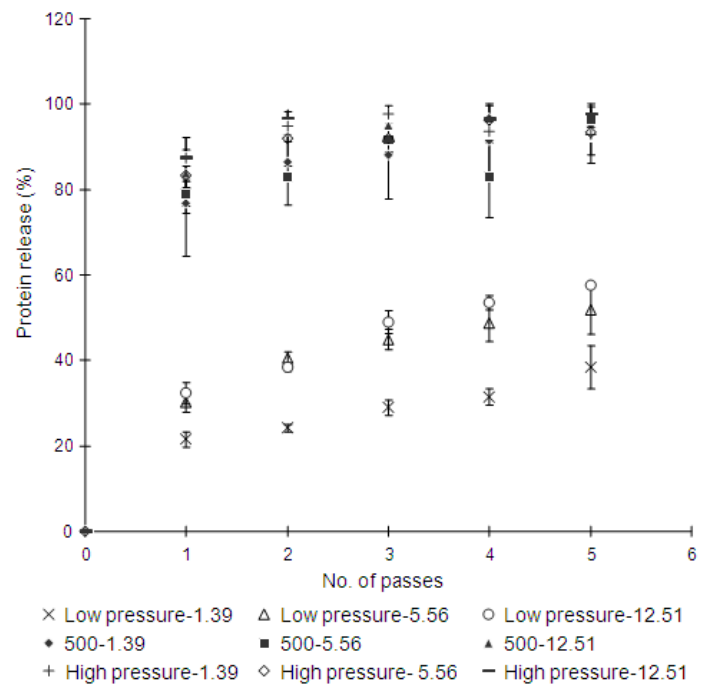

Fig. 3a: Protein release for different cell concentrations. The legend indicates the pressure and cell concentration. The data are the average of replicates. The error bars represents the standard error

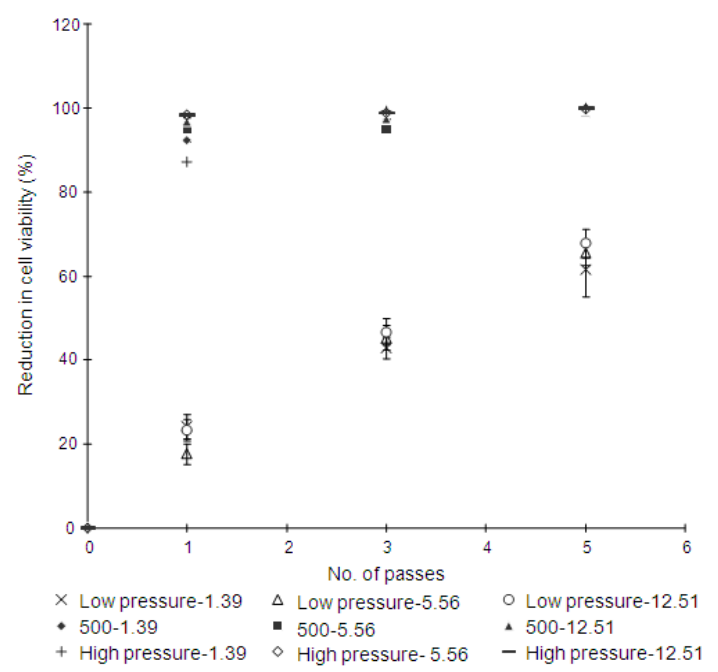

Fig. 3b: Reduction of cell viability for different cell concentrations. The legend indicates the pressure and cell concentration. The data are the average of replicates analyzed after 1,3 and 5 passes. The error bars represents the standard error

This difference was gradually increased with the increment of number of passes. This might be due to the low content of maximum protein and in turn due to the difference in the dilution factor between lower and higher content of maximum protein. On the other hand, similar profiles of PSD were seen for all the concentrations in all the pressure range (Fig. 3c). 


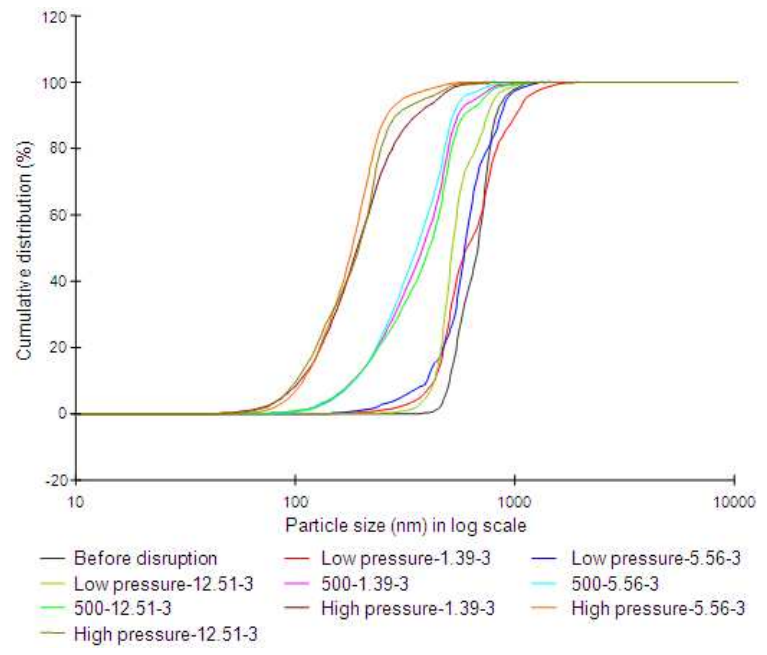

Fig. 3c: Cumulative distribution of different pressure ranges for different cell concentrations after three passes and before disruption. The legend indicates the pressure followed by cell concentration in $\mathrm{g} \mathrm{L}^{-1}$ and number of passes. The data are the average of replicates

Maximum protein and IFN- $\alpha 2 b$ release: Maximum protein release can be achieved in the transition and high pressure range. Both maximum protein and IFN- $\alpha 2 b$ release were similar with glass bead stirring (Table 1). At 500 bar maximum protein and IFN- $\alpha 2 b$ release was achieved with 3-4 passes while the same was achieved at 1000 bar with 1-2 passes and 1500 bar with 1 pass. Loss of antigenicity of IFN- $\alpha 2 b$ was not observed even at 1500 bar. The power requirement was calculated based on compressor power requirement and tabulated in Table 1. It should be noted that the exact power requirement would be more than the calculated value as the product has to be cooled.

Selective product release: High selectivity of product (IFN- $\alpha 2 b)$ release in homogenizer was achieved at low pressure range, which gave approximately twice the value of selectivity than high pressure range. Yet, when compared to osmotic shock which releases periplasmic protein the selectivity was five times lower.

\section{DISCUSSION}

Effect of pressure and number of passes: As mentioned in the result section, the maximum protein release was not achieved even after many no. of passes at 100 and 250 bar of homogenization operation. This is contrary to Hetherington et al. ${ }^{[16]}$, who reported that maximum amount of protein release is independent of pressure. However, the result of this study is similar to that reported by Limon-Lason et al. ${ }^{[17]}$, who explained that it was due to the release of insoluble protein complex and peptides through micronization of cell debris at higher pressure. Cell disruption is a two step processes which involved point break of cell envelope and followed by disintegration of cell wall along with degradation of cell debris ${ }^{[3]}$. Foster ${ }^{[1]}$ reported that recombinant E. coli strains needed minimum of $4 \mathrm{kpsi}$ (275.9 bar) to break the cells. Perhaps below this pressure range and above the threshold pressure, the cell disruption stopped at the first step and the pressure applied was not enough to disintegrate cell wall.

The PSD results (Fig. 1a and 2a) may indicate that total disintegration of cell wall was not occurred at these pressure ranges. In fact, the bimodal distribution was observed in all the samples (Fig. 2a). The results observed is in agreement with Keshavarz et al. ${ }^{[13]}$, who found that the fermented grown cultures of Rhizopus nigricans were intact after two passes of homogenization at 100 bar. Balasundaram and Harrison ${ }^{[18]}$ too have reported that disruption of baker's yeast at 138 bar has a similar PSD to that of undisrupted yeast cells $(6.2-5.9 \mu \mathrm{m})$. This leads to the classification of this pressure range as low pressure range where total disintegration did not occur.

At 1000 and 1500 bar, the maximum protein release (Table 1) was achieved after 1 pass with two steps of disruption occurred simultaneously. Further increase in number of passes will contribute only to micronization of cell debris. Earlier reports claimed that increase in number of passes above certain pressure would cause micronization of cell debris and also reduction in viscosity ${ }^{[14,19]}$. It was also mentioned that micronization won't reduce the PSD much as if like total cell disintegration ${ }^{[12]}$. Even though the micronization was observed in this pressure range, there was not much variation in viscosity (result not shown here). The cell concentration range $(0.14 \% \mathrm{DCW}$ to $1.25 \% \mathrm{DCW})$ used in this study might not be significant to see the viscosity variation. Similar result was observed by Balasundaram and Harrison ${ }^{[18]}$ where $5 \%$ wet concentration of baker's yeast was used in their study.

However, slightly different observation on the PSD at this pressure range were reported by other researchers ${ }^{[15,20]}$. Bury et al. ${ }^{[15]}$ reported that at 1350 bar, their product release was increasing up to 3 pass but then similar release was noticed at 2000 bar in 1 pass. This is due to the employment of gram positive microorganism (Lactobacillus delbrueckii ssp. bulgaricus) in their study which needs high strength to disrupt the cell wall. At 1600 bar, Van Hee et al. ${ }^{[20]}$ observed an increase of IB with increasing number of passes for the disruption of 
Pseudomonas Putida without any note of soluble protein content. IB is not the original content of soluble component and has increased due to the micronization of cell debris which was in agreement with Limon-Lason et al. ${ }^{[17]}$. So this pressure range can be classified as high pressure range where the maximum protein release and lower particle size can be achieved after the first pass of homogenization.

At 500 bar, major portion of PSD (Fig. 1b and 2b) still could be seen near to the whole cell region leading to trimodal distribution curve after 1 pass. With the increase in number of passes the curve became bimodal which is different from the bimodal curve of low pressure range. Recently, Balasundaram and Harrison ${ }^{[18]}$ mentioned that they had observed bimodal distribution for baker's yeast after 5 pass at 414 bar. Since both the characteristics of low pressure and high pressure range was observed this could be classified as transition pressure range.

Maximum protein and IFN- $\alpha 2 b$ release: The result shows that the maximum protein and IFN- $\alpha 2 b$ release could be achieved above low pressure range but depends on both the pressure applied and number of passes in homogenization operation. Increasing the number of passes increases the running time and also makes the cell disruption process as batch wise rather than continuous mode. In contrast, increasing the pressure reduces the volumetric flow rate but also reduces the number of passes. The difference in power requirement between 500-1000 and 1000-1500 bar was similar but the difference in process time was increased drastically.

While comparing the protein release (Table1) and the PSD analysis (Fig. $1 \mathrm{~b}$ and 2b) it is clear that micronization of cell debris was not necessary for maximum protein release and also for maximum IFN- $\alpha 2 b$ release. Yet it depends on the further downstream operation that follows the cell disruption. High particle size with low viscosity would be useful for centrifugal separation and dead-end filtration ${ }^{[1,14]}$, but low particle size accompanied with low viscosity would be beneficial for anionic expanded bed adsorption ${ }^{[18,21-24]}$. On the other hand, the characteristics of homogenates is not an affecting factor in cross flow filtration $^{[19]}$.

Selective product release: The result shows that even at low pressure range, release of protein was not limited to periplasmic area. SDS-PAGE analysis (Fig. 4) shows that the profile of low pressure range was similar to high pressure range. In both cases, high molecular weight proteins were observed in higher concentration than osmotic shock. This is in line with other mechanical

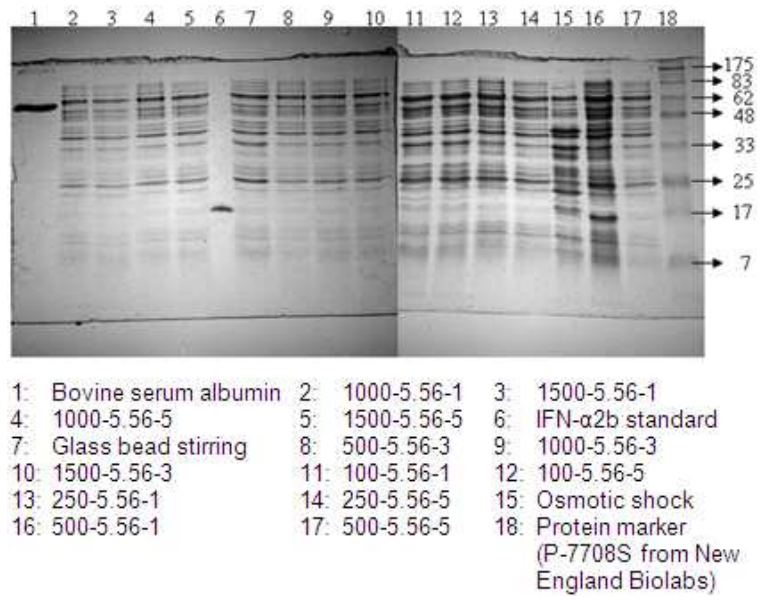

Fig. 4: SDS-PAGE passed through different stages of homogenizer along with osmotic shock and glass bead stirring. Legend of samples passed into high pressure homogenizer were denoted as pressure in bar followed by cell concentration in $\mathrm{g} \mathrm{L}^{-1}$ and number of passes. The approximate amount of protein loaded in all the sample wells was between 8 and $15 \mu \mathrm{g}$

disruption $^{[25-27]}$. For example, Balasundaram and Harrison $^{[27]}$ had observed $67 \% \quad \beta$-galactosidase (cytoplasmic high molecular weight protein) with $48 \%$ of total protein in their optimized hydrodynamic cavitation method for cell disruption. Middelberg ${ }^{[5]}$ pointed out that disruption through mechanical method is non specific and hence selective product release is not limited to the release of periplasmic protein release. In case of $E$. coli, the strength depends mainly on outer cell wall which consists of peptidoglycan layer. Once broken, the inner cell wall does not have enough strength to resist unless it is stabilized osmatically. High selective protein release would be generally preferred for further downstream processing as it reduces the impurities in chromatography system and also easier for centrifugation and dead end filtration as the cells are still intact. However, the selective product release conducted at lower pressures was captured only low product in expanded bed mode operation due to the higher interaction between yeast cell debris and anionic beads $^{[18]}$.

\section{CONCLUSION}

This study demonstrated that the cell disruption characteristics varied differently with different pressure ranges. At low pressure range, the cells were experienced point-break losing the soluble content partly 
but without the total disintegration of cell wall. Selective product was achieved in this range but maximum protein release might not be possible even after many numbers of passes. At transition pressure range the protein release and the PSD varied significantly, with the increment in number of passes leading to maximum protein release and micronization of cell debris. At high pressure range, the maximum protein release and the total disintegration was attained after the first pass and further increase in passes will cause only micronization of cell debris. The fact that the release of protein and the reduction of particle size did not tally each other was clearly due to the difference in cell disruption characteristics at different pressure ranges. The selection of process condition shall be based on the subsequent downstream operation to be employed, optimal power and time requirement.

\section{ACKNOWLEDGEMENT}

This study was funded by the Ministry of Science, Technology and Innovation, Malaysia under the SR IRPA research grant (Project Number: 03-02-04 SR2010 SR0008/05). CFU experiment was performed by Ms. Azulia Zoolkiflie and Mr. Sam Tek Sing which was their part of undergraduate study. Ramanan is a recipient of graduate research fellowship from University Putra Malaysia.

\section{REFERENCES}

1. Foster D., 1995. Optimizing recombinant product recovery through improvements in cell-disruption technologies. Curr. Opin. Biotechnol., 6: 523-526. DOI: 10.1016/0958-1669(95)80086-7

2. Harrison, S.T.L., 1991. Bacterial cell disruption: A key unit operation in the recovery of intracellular products. Biotechnol. Adv., 9: 217-240. DOI: 10.1016/0734-9750(91)90005-G.

3. Moore, E.K., M. Hoare and P. Dunnill, 1990. Disruption of baker's yeast in a high-pressure homogenizer: New evidence on mechanism. Enzyme Microb. Technol., 12: 764-770. DOI: 10.1016/0141-0229(90)90149-K

4. Kleinig, A.R. and A.P.J. Middelberg, 1998. On the mechanism of microbial cell disruption in high-pressure homogenisation. Chem. Eng. Sci., 53: 891-898.

DOI: 10.1016/S0009-2509(97)00414-4

5. Middelberg, A.P.J., 1995. Process-scale disruption of microorganisms. Biotechnol. Adv., 13: 491-551. DOI: 10.1016/0734-9750(95)02007-P
6. Diels, A.M.J., J. De Taeye and C.W. Michiels, 2005. Sensitisation of Escherichia coli to antibacterial peptides and enzymes by high-pressure homogenisation. Int. J. Food Microbiol. 105: 165-175. DOI: 10.1016/j.ijfoodmicro.2005.04.027

7. Lovering, A.L. and N.C.J. Strynadka, 2007. High-resolution structure of the major periplasmic domain from the cell shape-determining filament MreC. J. Mol. Biol., 372: 1034-1044. DOI: 10.1016/j.jmb.2007.07.022

8. Lario, P.I., R.A. Pfuetzner, E.A. Frey, L. Creagh, C. Haynes, A.T. Maurelli and N.C.J. Strynadka, 2005. Structure and biochemical analysis of a secretin pilot protein. EMBO J., 24: 1111-1121. DOI: $10.1038 /$ sj.emboj.7600610

9. Ramanan, R.N., T.C. Ling and A.B. Ariff, 2008. The Performance of a glass bead shaking technique for the disruption of Escherichia coli cells. Biotechnol. Bioprocess Eng., 13: 613-623. DOI: 10.1007/s12257-008-0047-y

10. Chen, Y.C., L.A. Chen, S.J. Chen, M.C. Chang and T.L. Chen, 2004. A modified osmotic shock for periplasmic release of a recombinant creatinase from Escherichia coli. Biochem. Eng. J., 19: 211-215. DOI: 10.1016/j.bej.2004.03.001

11. Bradford, M.M., 1976. A rapid and sensitive method for the quantitation of microgram quantities of protein utilizing the principle of protein dye binding. Anal. Biochem., 72: 248-254. DOI: $10.1016 / 0003-2697(76) 90527-3$

12. Siddiqi, S.F., N.J. Titchener-Hooker and P.A. Shamlou, 1996. Simulation of particle size distribution changes occurring during high-pressure disruption of bakers' yeast. Biotechnol. Bioeng., 50: 145-150. DOI: 10.1002/(SICI)1097-0290(19960420)50:2<145::AID-BI T4>3.0.CO;2-M

13. Keshavarz, E., J. Bonnerjea, M. Hoare and P. Dunnill, 1990. Disruption of a fungal organism, rhizopus nigricans, in a high-pressure homogenizer. Enz. Microb. Technol., 12: 494-498. DOI: 10.1016/0141-0229(90)90064-W

14. Agerkvist, I. and S.O. Enfors, 1990. Characterization of $E$. coli cell disintegrates from a bead mill and high pressure homogenizers. Biotechnol. Bioeng., 36: 1083-1089. DOI: 10.1002/bit.260361102

15. Bury, D., P. Jelen and M. Kaláb, 2001. Disruption of Lactobacillus delbrueckii ssp. bulgaricus 11842 cells for lactose hydrolysis in dairy products: A comparison of sonication, high-pressure homogenization and bead milling. Innovat. Food Sci. Emerg. Tech., 2: 23-29. DOI: 10.1016/S1466-8564(00)00039-4 
16. Hetherington, P.J., M. Follows, P. Dunnill and M.D. LlLly, 1971. Release of protein from baker's yeast (Saccharomyces Cerevisiae) by disruption in an industrial homogenizer. Chem. Eng. Res. Des., 49: 142-148.

http://archive.icheme.org/cgi-bin/somsid.cgi?type= header\&record $=1188$

17. Limon-Lason, J., M. Hoare, C.B. Orsborn, D.J. Doyle and P. Dunnill, 1979. Reactor properties of a high-speed bead mill for microbial cell rupture. Biotechnol. Bioeng., 21: 745-774. DOI: 10.1002/bit.260210503

18. Balasundaram, B. and S.T.L. Harrison, 2008. Influence of the extent of disruption of Bakers' yeast on protein adsorption in expanded beds. J. Biotechnol., 133: 360-369. DOI: 10.1016/j.jbiotec.2007.07.724

19. Bailey, S.M. and M.M. Meagher, 1997. Crossflow microfiltration of recombinant Escherichia coli lysates after high pressure homogenization. Biotechnol. Bioeng., 56: 304-310. DOI: 10.1002/(SICI)1097-0290(19971105)56:3<304::AI D-BIT8>3.0.CO;2-N

20. Van Hee, P., A.P.J. Middelberg, R.G.J.M. Van Der Lans and L.A.M. Van Der Wielen, 2004. Relation between cell disruption conditions, cell debris particle size, and inclusion body release. Biotechnol. Bioeng., 88: 100-110. DOI: 10.1002/bit.20343

21. Balasundaram, B., S.T.L. Harrison, J. Li and H.A. Chase, 2008. A study of the influence of yeast cell debris on protein and $\alpha$-glucosidase adsorption at various zones within the expanded bed using in-bed sampling. Biotechnol. Bioeng., 99: 614-624. DOI: 10.1002/bit.21586
22. Hubbuch, J.J., P.J. Brixius, D.Q. Lin, I. Mollerup and M.R. Kula, 2006. The influence of homogenisation conditions on biomass-adsorbent interactions during ion-exchange expanded bed adsorption. Biotechnol. Bioeng., 94: 543-553. DOI: 10.1002/bit.20850

23. Vennapusa, R., S.M. Hunegnaw, R.B. Cabrera and M. Fernández-Lahore, 2008. Assessing adsorbent-biomass interactions during expanded bed adsorption onto ion exchangers utilizing surface energetics. J. Chromatogr. A., 1181: 9-20.

24. Lin, D.Q., J.N. Dong and S.J. Yao, 2007. Target control of cell disruption to minimize the biomass electrostatic adhesion during anion-exchange expanded bed adsorption. Biotechnol. Prog., 23: 162-167. DOI: 10.1021/bp060286x

25. Balasundaram, B. and A.B. Pandit, 2001. Selective release of invertase by hydrodynamic cavitation. Biochem. Eng. J., 8: 251-256. DOI: 10.1016/S1369-703X(01)00114-0

26. Bakir, U. and H. Hamamci, 1997. The effect of freeze-thawing on the release of intracellular proteins from Escherichia coli by means of a bead mill. World. J. Microbiol. Biotechnol., 13: 475-477. DOI: $10.1023 / \mathrm{A}: 1018592604304$

27. Balasundaram, B. and S.T.L. Harrison, 2006. Study of physical and biological factors involved in the disruption of $E$. coli by hydrodynamic cavitation. Biotechnol. Prog., 22: 907-913. DOI: 10.1021/bp0502173 